\title{
Variation in ecological risk at three Nevada gold mines over a ten year post-closure period
}

\author{
E.A. Robinson SRK Consulting (UK) Ltd, UK
}

\begin{abstract}
This case study considers screening-level ecological risk assessment as a complementary technique to traditional rehabilitation monitoring methods for growth and productivity by evaluating the change in ecological risk from heap leach draindown over time. Available data from three Nevada gold mines were examined for a ten year post-closure period. The study found that variation in ecological risk can be used to plan adaptive management approaches in response to changing risks and liabilities. However, the likelihood of implementing new management approaches post-closure remains in question.
\end{abstract}

\section{Introduction}

Ecological Risk Assessment (ERA) is defined as a prediction tool which evaluates the likelihood that adverse ecological effects may occur or are occurring as a result of exposure to human-induced stressors (USEPA, 1992; SETAC, 1997). In the context of environmental management, ERA is used to consider 'what if' scenarios, facilitate identification of environmental values of concern, and highlight critical information gaps that could be the focus of future research efforts (SETAC, 1997). A framework for ERA was developed by the United States Environmental Protection Agency (USEPA) and Environmental Sciences Division of Oak Ridge National Laboratory (ORNL) in 1983. Passage of the Superfund legislation in the United States in 1980 led to a predominant use of the ERA technique for remediation of contaminated sites through the late 1980s and 1990s in the United States (Suter, 2008).

During the mid-1990s, ERA became a popular predictive method to evaluate potential risks from mine sites. Waste management techniques during the operating period and mine closure methods aim to reduce exposure to hazardous constituents in the long-term. However, metal leaching from poorly managed mine waste storage facilities, exposed pit lakes, and heap leach pad draindown may continue to pose toxicological risks to receptors long after the facility has been closed, and even after sureties have been used or released (Sampson et al., 1996). ERA is now used more widely across the industry to predict ecological risks and to inform the selection of appropriate closure actions.

While ERA is increasingly being used to predict potential risks during the closure period, there is little evidence of ERAs being used as a post-hoc evaluation tool during, or after, the actual rehabilitation process. This study aims to understand whether there is a case for conducting ERAs on a periodic basis to monitor the success of the implemented management measures by tracking changes in ecological risk through the rehabilitation time frame. While it may seem illogical to look at risks retrospectively, given that they relate to future scenarios, analysis of historic data is useful to elucidate trends that may extend into the future (Suter, 2007). Understanding variation in ecological risk could allow managers to change the priority of rehabilitation actions and resources in response to the changing risk patterns. An adaptive and dynamic approach to rehabilitation may increase efficiency for the mine site and make managers aware of changing liabilities as a site recovers. To be a useful evaluation tool, the periodic ERAs must also be simple to integrate into the wider rehabilitation monitoring programme.

Three case study sites were selected to test the application of ERA as a post-closure, rehabilitation monitoring method. Nevada State is located in the western United States and has a landscape of closed and abandoned mine sites that have either been actively rehabilitated or have recovered naturally to varying degrees. This State therefore presents rehabilitation examples that can be drawn upon for this study. 
Common features of many closed Nevada mines are rehabilitated heap leach pads which continue to release small quantities of drainage throughout the closure and post-closure period as a result of rainwater infiltrating through the soil cover. If discharged to the surface, this draindown may pose an ecological risk to surrounding wildlife and livestock receptors. Changes in the chemistry of heap leach draindown have therefore been used to indicate changes in ecological risk from these sites over the rehabilitation timeframe.

A Screening Level Ecological Risk Assessment (SLERA) is one of many types of ERA and was selected as an appropriate assessment tool for this study, as it represents the initial level of risk assessment complexity and conservatism to determine if further analysis of risks is warranted. There are clear limitations associated with using a preliminary method for analysis and the results from the study should be considered in light of these limitations. Furthermore, the focus on only a narrow sub-set of potential ecological receptors in this study (wildlife and livestock) may discount the risk posed to other organisms, such as soil microbiota, that play a fundamental role in ecosystem dynamics and the success of rehabilitation.

\section{$2 \quad$ Methodology}

\subsection{Site selection}

Three closed gold mines in Nevada were selected as case studies to evaluate the potential change in ecological risk; Griffon Mine, Mount Hamilton Mine and Aurora Mine. All three mines have a heap leach pad regularly monitored by the US Forest Service (USFS), resulting in publically available data.

Griffon Mine was identified as the primary case study site and has been closed for approximately ten years. The site was considered suitable for this study as the draindown from the old heap leach pad is expressed directly to the surface, creating a surface water pond/wetland, which is accessible to wildlife and livestock.

The Mount Hamilton and Aurora mines were selected as analogue sites to understand whether the results from Griffon are characteristic of other similarly rehabilitated heap leach pads. They were closed at a similar time period to Griffon and therefore have a comparable period of draindown chemistry data. Mount Hamilton is located in east Nevada close to Griffon whereas Aurora is located in the west of the State (Figure 1).

Both selected analogue sites currently discharge draindown solution from the closed heap leach pads to sub-surface infiltration systems, resulting in an incomplete exposure pathway for the chemical stressors to come into contact with wildlife receptors. For this study, however, it was assumed that the draindown is discharged to surface to present a hypothetical exposure pathway. If the hypothetic exposure scenario indicates a low risk, actual discharge of the solution to the surface could be considered as a potential adaptive management opportunity.

\subsubsection{Griffon Mine}

The Griffon Mine is located in White Pine County, east Nevada, $50 \mathrm{~km}$ southwest of the town of Ely (Figure 1). The site is between 2,150 $\mathrm{m}$ and 2,450 $\mathrm{m}$ elevation and has warm, dry summers and cold, moist winters. Average minimum and maximum temperatures range from $-16^{\circ} \mathrm{C}$ in January to $27.1^{\circ} \mathrm{C}$ in July with an annual average of $3.5^{\circ} \mathrm{C}$. Average annual rainfall is $50 \mathrm{~cm}$ (SRK, 2000a) which falls mainly between November and April.

Exploration began at the property in the mid 1980s, and mine development followed in 1997. Gold was extracted from mined ore using heap leach pad processing. The pad covered a surface area of approximately $98,000 \mathrm{~m}^{2}$ at its maximum size (SRK, 2000a). The heap was constructed on a 1.5 to $2 \mathrm{~mm}$ thick High Density Polyethylene (HDPE) liner, which in turn was placed on $30 \mathrm{~cm}$ of compacted, low permeability soils, with a leak detection system (SRK, 2000a). 


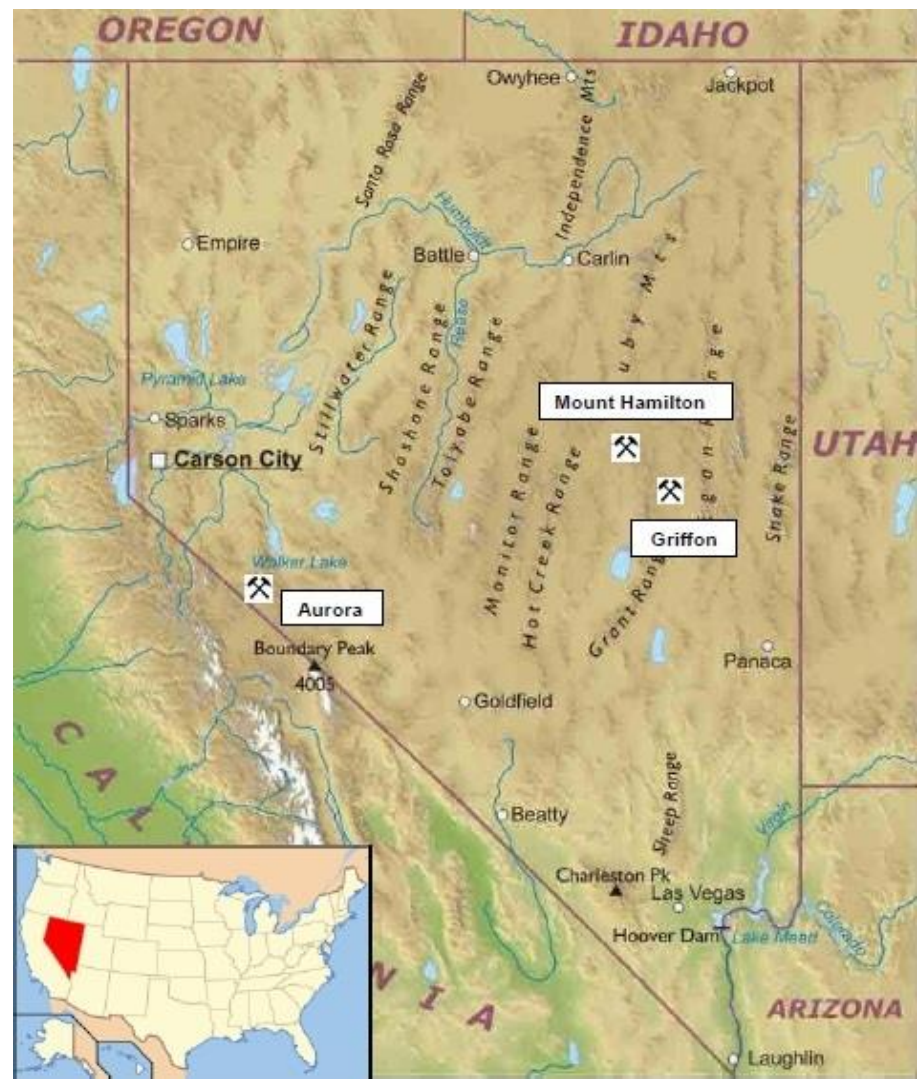

\section{Figure 1 Location of Griffon, Mount Hamilton and Aurora mines in Nevada Source: Adapted from World Maps (http://www.worldmapsinfo.com/)}

Alta Gold Company (Alta Gold) became owners of the Griffon property in 1994, but filed for bankruptcy in April 1999. At that time, all mining operations ceased, although cyanide addition continued until January 2000. The property was put into a care and maintenance mode to manage the residual drainage waters from the heap leach drainage process (SRK, 2000a) until closure works were carried out in 2001. As Alta Gold was bankrupt by this time and financial sureties filed for the site were found to be insufficient for the required closure activities, the land manager, USFS, became responsible for the closure of the site.

Closure of the heap leach pad involved placement of drainpipes in the solution ditches and stabilisation of stormwater diversion ditches around the perimeter of the heap. The heap slopes were regraded to $3 \mathrm{H}: 1 \mathrm{~V}$ and a composite soil cover was placed on the regraded slopes to prevent erosion, limit infiltration into and seepage out of the heap, and encourage revegetation. The heap cover consisted of approximately $30 \mathrm{~cm}$ of inert waste rock and $30 \mathrm{~cm}$ of gravel-based growth medium (SRK, 2000a). The heap draindown solution that was in the heap at the time of closure was collected and disposed of via land application. Following an evaluation of viable options, future draindown from fresh surface water inputs (from precipitation) was directed to a surface pond that discharges directly to the environment, which is accessible to wildlife and livestock.

\subsubsection{Mount Hamilton Mine}

Mount Hamilton Mine is located $55 \mathrm{~km}$ west of the town of Ely in White Pine County, Nevada. The site has an arid climate with average maximum temperature of $31.5^{\circ} \mathrm{C}$ in July and average minimum temperature of $-11^{\circ} \mathrm{C}$ in December. Average annual precipitation from 2002 to 2011 was $22.3 \mathrm{~cm}$ rain and $120 \mathrm{~cm}$ snowfall (Western Regional Climate Centre, 2011a). Longer-term data suggest that average precipitation is around $35 \mathrm{~cm}$ (Geomega, 2000). The vegetation community at the site consists mostly of pinyon pine-juniper communities with soils of loamy sand with gravel on the upper slopes and sage-brush and grasses on lower slopes and in the valley. Groundwater is approximately $152 \mathrm{~m}$ below ground surface (Geomega, 2000). 
Rea Gold Corporation owned and operated Mount Hamilton from 1994. The leach pad covered an area of $93,000 \mathrm{~m}^{2}$ at a height of $18 \mathrm{~m}$. During operations, the effluent from the pad was contained in a bermed liner and reported to one of three ponds from where the solution was sent to be processed. Rea Gold Corporation went bankrupt in 1998 and the site was abandoned. Similar to Griffon, the financial surety filed for Mount Hamilton was also found to be insufficient; therefore, the USFS land managers became responsible for closure of the site.

Closure activities were conducted in October 2000 and included regrading the slopes of the heap to a slope ratio of 3:1 and placement of a cover over the heap (USDA, 2000). The cover consisted of $20 \mathrm{~cm}$ of lowpermeability borrow material and $12 \mathrm{~cm}$ of topsoil and was revegetated with (in order of density) Thickspike wheatgrass (Agropyron dasystachyum), Indian ricegrass (Oryzopsis hymenoides), Fourwing saltbrush (Atriplex canescens), Northern sweetvetch (Hedysarum boreale), Sandberg's bluegrass (Poa sandbergii), Blue flax (Linum lewisii) and Palmer penstemon (Penstemon palmeri) (USDA, 2000). Mulch (alfalfa hay) was applied over the reseeded area (USDA, 2000). The effluent from the heap leach pad was directed to a sub-surface infiltration system.

\subsubsection{Aurora Mine}

The Aurora Mine is located $35 \mathrm{~km}$ southwest of the town of Hawthorn, in western Nevada, and is situated around 2,200 m elevation. The average annual precipitation for the site is $33 \mathrm{~cm}$ which mostly falls as snow during the winter months. Monthly average temperatures from the closest climate station (Bodie, California) range from a maximum of $25^{\circ} \mathrm{C}$ in July to $-14.5^{\circ} \mathrm{C}$ in January (Western Regional Climate Centre, 2011b). The vegetation community mostly consists of pinion pine-juniper species with sandy, silty-clay soils. Due to deep sandy soils in the surrounding area of Gregory Flats, no perennial surface water bodies are present however two ephemeral springs occur $0.8 \mathrm{~km}$ to the south-southwest and $1.5 \mathrm{~km}$ to the west of the heap leach pad (SRK, 2000b).

Aurora began operations in 1987. The heap leach pad covers approximately $112,000 \mathrm{~m}^{2}$ and was constructed on a HDPE liner over a compacted clay base (SRK, 2000b). The site was owned and operated by The Aurora Partnership who declared bankruptcy in 1999 and abandoned the site. Site ownership reverted to the USFS, who became responsible for closure.

Closure activities at Aurora occurred in late 2000 and early 2001, and activities for the heap leach pad were similar to those at Griffon. They included regrading the heap to slopes of 3:1 and placing an engineered cover to reduce infiltration and erosion. The cover design for Aurora was $30 \mathrm{~cm}$ of waste rock and approximately $20 \mathrm{~cm}$ of topsoil (SRK, 2000b). The cover was revegetated following the completion of final earthworks with the following salt-tolerant, shallow-rooting grasses; greasewood (Sarcobatus vermiculatis), Great Basin wildrye (Elymus cinereus), Bottlebrush squirreltail (Sitanion hystrix), Sandberg bluegrass (Poa sandbergii), and Nuttal's alkali grass (Puccinellia airoides). The solution inventory within the heap was disposed via land application prior to and during construction and long-term effluent drainage was directed to a sub-surface infiltration field in a pre-disturbed area of the site (SRK, 2000b).

\subsection{Screening-level ecological risk assessment}

A SLERA is composed of three discrete phases: problem formulation, analysis, and risk characterisation. This section describes how the three phases were applied to the study.

\subsubsection{Problem formulation}

As described by the United States Environmental Protection Agency (USEPA, 1998), problem formulation begins with the evaluation of available information on sources, stressors, effects and receptors to define the problem that needs assessing. Specifically the problem formulation process of a SLERA should:

- Describe the physical and ecological setting of the site.

- Provide an evaluation of contaminant sources that may be present. 
- Identify the categories of receptors that may be affected by the identified contaminants.

- Develop the ecological conceptual site model that shows relationships between a source and a receptor.

- Identify the assessment endpoints and measures that adequately reflect management goals (USEPA, 1997).

Background information, current contamination sources, and potential receptors were obtained from previous studies conducted at the three mines. These studies included Environmental Impact Statements (EIS), plans of operations, and closure plans. As the primary case study site, conditions at the Griffon Mine were used to define the parameters and baseline assumptions for the problem formulation phase of the SLERA process. The same parameters and assumptions were used for the analogue sites to facilitate comparison of the analysis and risk characterisation results.

Ecological receptors for the SLERA were identified from baseline data presented in the Environmental Impact Statement (EIS) prepared for Griffon. For the purposes of this study, receptors were limited to mammals and birds due to the availability of exposure factors (body weights, consumption rates, etc.) and toxicological testing data on these species. The EIS also states that no threatened or endangered animal species were identified at the Griffon site; however, three bat species of concern occur in the vicinity of Ellison Creek (USDA, 1997). Common rodents such as deer mouse and cottontail rabbit were identified, and elk and mule deer range cover the entire site. Sensitive bird species, such as raptor species, were also identified as present. Livestock graze close to Griffon, therefore, cattle are also considered to be receptors. The author acknowledges the limited species set does not take into account soil microbes and the risks posed to them, potentially affecting a fundamental aspect of ecosystem dynamics.

The main management goal for this SLERA was to protect wildlife from unreasonable adverse effects from draindown released from rehabilitated heap leach pads into the surface water pond. The primary assessment endpoint identified to meet this goal was therefore defined as growth, development and reproduction (survival) of local populations of wildlife and livestock. As it is unrealistic to measure these endpoints directly in the context of a preliminary screening assessment, ecotoxicity screening values were selected as surrogate measurement endpoints to represent changes in the assessment endpoint of the SLERA. The selection of appropriate ecotoxicity values is described below.

The conceptual site model (Figure 2) was developed using site ecological conditions, exposure assumptions, potential ecological receptors, and assessment endpoints. The most relevant, direct and potentially complete exposure pathway for the wildlife receptors was found to be through direct contact and ingestion of surface water from the wetland.

\subsubsection{Analysis}

\subsubsection{Exposure assessment}

The source of ecological stressor for all three sites is potentially contaminated water discharging from the base of the heap leach pad. The exact concentrations of the chemical stressors have been monitored through regular sampling of the draindown solution, prior to, during and following closure of the sites.

Time-sequenced draindown water chemistry data for the selected sites were obtained from the NDEP. For Griffon, results from 22 water quality samples were used, spanning a 10 year monitoring period between February 1999 and September 2009. For Mount Hamilton, 16 water quality samples from between September 2000 and September 2009 were analysed, and for Aurora, data from 25 water quality samples, collected between February 1998 and August 2010, were used. These data span operational conditions, site abandonment, closure and post-closure. 


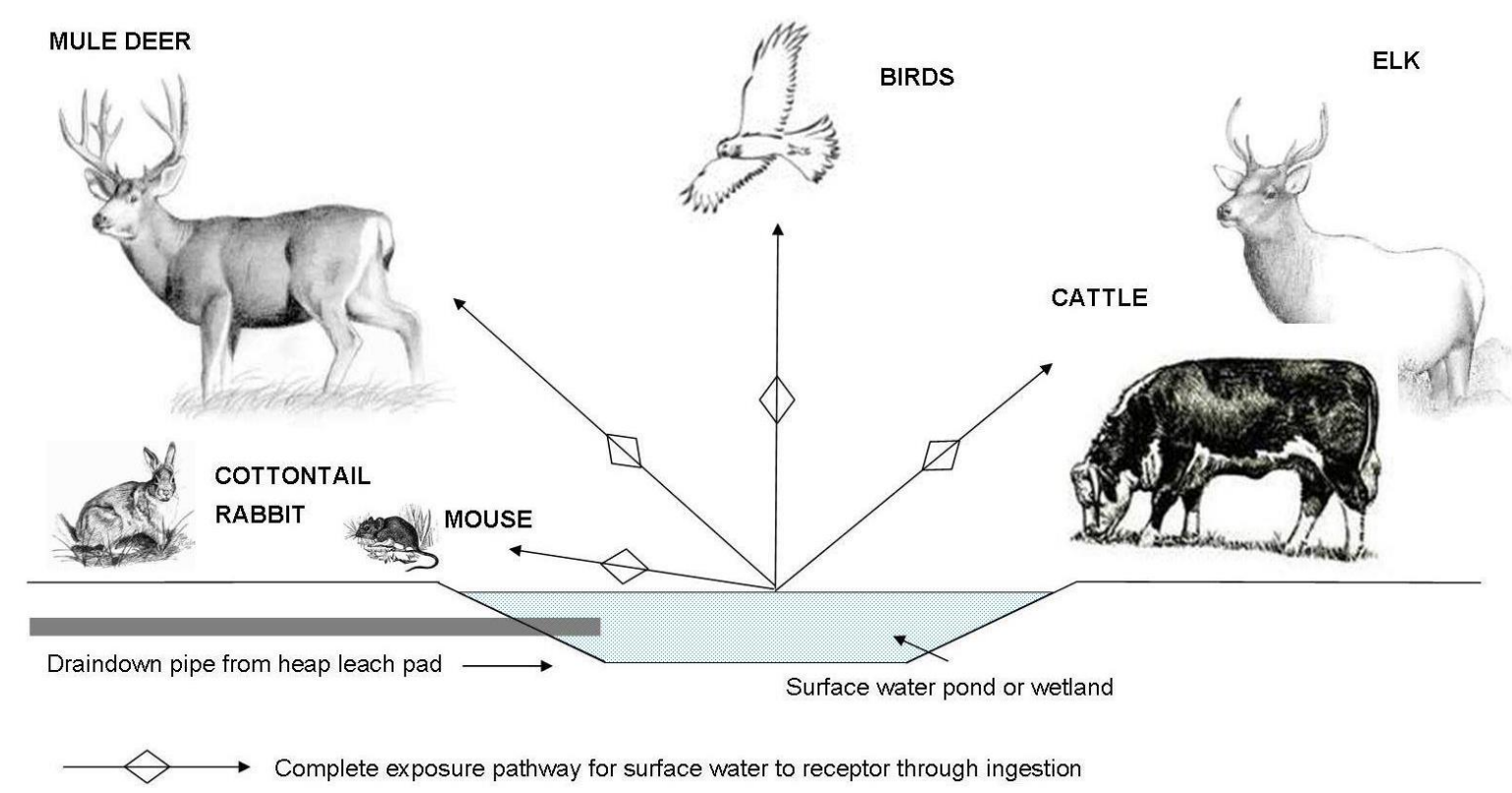

\section{Figure 2 Conceptual site model}

At the Griffon site, the draindown solution from the heap is directly discharged to the surface, forming a pond or wetland area. Within the context of this study, it is assumed that the draindown solutions for Mount Hamilton and Aurora have also been discharged to surface since closure of the heap leach pad, resulting in an open water wetland. Contact between the chemical stressor and the wildlife receptors occurs through direct ingestion of the surface water. In response to uncertainties about wetland use, it was conservatively assumed that the surface expression of draindown water is the main water source for the receptors on a year-round basis for their entire lifetimes. Exposure to the chemical stressor is therefore assumed to be continual.

Exposure of the stressor may also transfer to the receptor through a dermal pathway if the surface water comes into contact with the skin of the identified receptors. In comparison to drinking, this pathway is considered to be minor. Inhalation is also considered to be a minor pathway for the metal-based stressors, as they are not highly volatile. As such, both dermal contact and inhalation were not considered complete or viable exposure pathways for this study.

\subsubsection{Ecological effects assessment}

As recommended by USEPA (1997), ecotoxicity screening values should represent No Observed Adverse Effects Levels (NOAELs). Study-specific NOAELs were selected from State and federal ambient water quality standards, and ecotoxicity criteria for concentrations of metals in water. The following standards were evaluated:

- Nevada Beneficial Use Criteria for Propagation of Wildlife 2006 revision (NAC, 2011).

- Nevada Beneficial Use Criteria for Watering of Livestock 2006 revision (NAC, 2011).

- U.S. Environmental Protection Agency Water Quality Criteria (USEPA, 1972) for livestock water.

- Species-specific ecotoxicity criteria (Sample et al., 1996) (four surrogate animals were selected to represent the identified wildlife receptors).

The most stringent set of criteria (and therefore most conservative) of the group was the USEPA Water Quality Criteria for livestock followed by the Nevada Beneficial Use Criteria for Livestock. As livestock criteria are developed to protect a large variety of animal species (poultry, pigs, sheep and cattle) they were considered an appropriate measure for the variety of wildlife receptors identified for the study and were therefore preferentially selected for defining the site specific NOAELs. Where values were not 
available from these criteria, the most stringent toxicity values from Sample et al. (1996) were used. Due to the lack of parameters provided in the wildlife criteria they were not useful for the SLERA.

\subsubsection{Risk characterisation}

The risk characterisation process estimates the likelihood of risks to ecological receptors from exposure to concentrations of metal constituents of concern. The chemical-specific hazard quotient (HQ) risk method is commonly used for deterministic risk characterisation in SLERAs. It is an efficient method to identify high or low risk situations so that risk management decisions can be made without large quantities of information (USEPA, 1998). The HQ risk characterisation approach is particularly common for sites located close to residential areas (in a human health risk capacity), and is also relevant for toxicological effects on ecological receptors. The HQ ratio compares an exposure estimate (for example a media chemical concentration) to a toxicity reference value or benchmark, such as a media-specific ecotoxicity screening value (Sorensen et al., 2004).

$$
H Q=\frac{\text { Exposure Concentration }}{\text { Threshold Criteria }} \leq 1.0
$$

While the dose-response for a given analyte on which a toxicity reference value is based is not necessarily linear, an analyte with an $\mathrm{HQ}$ of 1.1 is less likely to present a substantive risk to an ecological receptor than an analyte with an $\mathrm{HQ}$ of 10 , or even 100 . The following approach to characterising risk in relation to exposure thresholds and toxicological criteria was adapted from Risk Management Criteria for Metals at BLM Mining Sites (Bureau of Land Management (BLM), 2004):

- Less than criteria $(\mathrm{HQ}<1)=$ 'Low' Risk.

- $1-10$ times the criteria ( $\mathrm{HQ}=1$ to 10$)=$ 'Moderate' Risk.

- $10-100$ times the criteria $(H Q=10$ to 100$)=$ 'High' Risk.

- $>100$ times the criteria $(H Q>100)=$ 'Extremely High' Risk.

If the estimated exposure level to the wildlife receptor is lower than one, then the chemical is unlikely to represent a toxicological risk under normal site conditions.

\subsection{Study considerations}

The following considerations were considered pertinent to the study:

- Precautionary approach: Conservative assumptions were made at each decision point so that risk would be over-estimated rather than under-estimated.

- Accuracy of secondary data: The secondary data used for the exposure assessment were collected by the USFS over a 10 year period and as such it is not possible to directly verify the samples collected. Although quality control measures indicated consistency over the ten years, it is possible that sampling methods may have changed and the accuracy of laboratory analysis could have altered.

- Wildlife receptors: The wildlife receptors were selected for the analysis using baseline data presented in the Griffon EIS (USDA, 1997). It is possible that since this information was collected, biological community compositions may have changed. In addition, the wildlife receptors at the analogue sites were assumed to be the same as Griffon. The proximity of Griffon to Mount Hamilton suggests this is a valid assumption but may be less accurate for Aurora.

- Exposure assumptions: It was assumed wildlife use the surface pond as their primary drinking water source for their entire lives (chronic exposure). Given the potential proximity of the sites to alternative freshwater sources this is unlikely but represented a conservative approach in the absence of specific pond usage information. 
- Toxicity of metals in draindown solution: The toxicity of many metals is dependent on their chemical form which is dictated by the physical-chemical characteristics such as $\mathrm{pH}$ and alkalinity of water. As many toxicity studies are conducted with highly soluble and readily bioavailable forms of metals (or organics) in food and/or water, the ecotoxicity values developed from these studies are, by default, conservative under most ambient conditions. The relative concentrations of more soluble ionic forms in the draindown solution were unknown and therefore a greater or lesser toxicological risk could be present.

- Analogue site assumptions: The Mount Hamilton and Aurora heap leach pads were assumed to discharge directly to surface and form a pond from which wildlife can drink regularly. This does not reflect the actual situation but was necessary to hypothesise about the potential risk from the heap leach pads should surface water discharge be implemented as a management option.

\section{$3 \quad$ Results}

\subsection{Comparison of NOAEL with draindown concentrations}

The selected NOAEL were compared against the heap leach solution chemistry across the entire data set for all three sites. Most parameters were found to be below the NOAEL. Table 1 shows the concentrations of metals found to be close to or elevated above the NOAEL in the first ten samples of the data set. The initial evaluation showed water quality in the Griffon draindown solution was good overall; however, three parameters may present a particular concern for wildlife. Thallium was consistently detected at concentrations above the NOAEL. Thallium can be toxic in chronically elevated concentrations and may cause adverse effects in the central nervous system and gastrointestinal tract when ingested. Reproductive effects in wildlife, such as depleted sperm counts, have also been shown to occur with high thallium (USACHPPM, 2007).

Nitrate was also elevated above the NOAEL following closure, predictably due to the natural degradation process of weak acid dissociable (WAD) cyanide. WAD cyanide can volatilise, adsorb onto surrounding solids, or oxidise to ammonia then to nitrate (MERG, 2001). Decreasing concentrations of cyanide over the same period support this supposition. Nitrate is toxic, particularly when converted to nitrite. Nitrite is easily absorbed into the blood stream and oxidises the ferrous iron in haemoglobin to ferric iron, decreasing the efficiency of oxygen transport in the blood which can be fatal (Strickland et al., 2009). Ruminant animals have micro-organisms in their digestive tract that speed this process and are therefore more susceptible to this form of toxicity.

Mercury was the final constituent in the Griffon draindown above its NOAEL for the first three samples of the data set when leachate was still being applied to the heap. Mercury is a toxic element that is efficiently absorbed from the gut and bioaccumulates within wildlife and humans due to a high degree of stability of the metal within body tissue (USEPA, 1972). It can damage the central nervous system, endocrine system, kidneys and can cause birth defects in foetuses.

From all the water quality parameters compared for Mount Hamilton, only arsenic, copper, nitrate and total dissolved solids (TDS) were over their respective NOAEL. Arsenic is toxic because it is a close chemical surrogate for phosphorus and therefore inhibits metabolic functions where it has substituted for phosphorus. Acute toxicological effects may include the death of animals. Arsenic has moderate chronic toxicity for birds and land animals and may result in shortened lifespan, reproductive problems, lower fertility, and changes in appearance or behaviour (USEPA, 1972). Nitrate and TDS show increasing concentrations within the draindown over time. Copper showed elevated concentration following the end of operations and start of closure, but then fell below the NOAEL. This is possibly due to copper's strong affinity to cyanide forming a ferrocyanide salt $\left(\mathrm{Cu}_{2}\left[\mathrm{Fe}(\mathrm{CN})_{6}\right]\right)$, that is highly soluble and will result in free copper in solution when in contact with water (ICMI, 2011). As the rate of infiltration declines following closure, less water is available to dissolve the salt and therefore the concentration of copper in solution falls. 
Table 1 Comparison of NOAELs with first ten samples of draindown concentrations (mg/L)

\begin{tabular}{|c|c|c|c|c|c|c|c|c|c|c|c|c|}
\hline Griffon & & NOAEL & $\begin{array}{c}01 \text { Feb } \\
1999\end{array}$ & $\begin{array}{c}01 \text { May } \\
1999\end{array}$ & $\begin{array}{c}01 \text { Aug } \\
1999\end{array}$ & $\begin{array}{c}01 \text { Nov } \\
1999\end{array}$ & $\begin{array}{c}01 \text { Feb } \\
2000\end{array}$ & $\begin{array}{c}08 \text { Sep } \\
2000\end{array}$ & $\begin{array}{c}09 \text { Oct } \\
2000\end{array}$ & $\begin{array}{c}23 \text { Aug } \\
2001\end{array}$ & $\begin{array}{c}15 \text { Nov } \\
2001\end{array}$ & $\begin{array}{c}22 \text { Apr } \\
2002\end{array}$ \\
\hline & Arsenic & 0.2 & 0.151 & 0.166 & 0.148 & 0.152 & 0.112 & 0.08 & 0.064 & 0.054 & 0.05 & 0.046 \\
\hline & Copper & 0.5 & 0.402 & 0.498 & 0.038 & 0.01 & 0.01 & 0.01 & 0.01 & 0.002 & 0.002 & 0.002 \\
\hline & Mercury & 0.01 & 0.207 & 0.097 & 0.015 & 0.002 & 0.001 & 0.0005 & 0.0005 & 0.0005 & 0.0005 & 0.0002 \\
\hline & Nitrate $\mathrm{N}$ & 100 & 49.9 & 44 & 68.6 & 65.2 & 120 & 136 & 153 & 140 & 140 & 120 \\
\hline & Thallium & 0.032 & 0.046 & 0.08 & 0.052 & 0.071 & 0.036 & 0.064 & 0.057 & 0.056 & 0.064 & 0.056 \\
\hline \multirow[t]{5}{*}{$\begin{array}{c}\text { Mt. } \\
\text { Hamilton }\end{array}$} & & & $\begin{array}{c}01 \text { Sep } \\
2000\end{array}$ & $\begin{array}{c}23 \text { Oct } \\
2000\end{array}$ & $\begin{array}{c}18 \mathrm{Apr} \\
2001\end{array}$ & $\begin{array}{c}19 \text { Apr } \\
2002\end{array}$ & $\begin{array}{c}25 \text { Jun } \\
2002\end{array}$ & $\begin{array}{c}07 \text { Oct } \\
2002\end{array}$ & $\begin{array}{c}22 \text { Jun } \\
2003\end{array}$ & $\begin{array}{c}16 \mathrm{Mar} \\
2004\end{array}$ & $\begin{array}{c}31 \text { Aug } \\
2004\end{array}$ & $\begin{array}{l}11 \mathrm{Jul} \\
2005\end{array}$ \\
\hline & Arsenic & 0.2 & 2 & 2.01 & 2.7 & 2.5 & 2.3 & 2.3 & 2.4 & 2.4 & 2.6 & 3.1 \\
\hline & Copper & 0.5 & 4.02 & 2.77 & 0.69 & 0.095 & 0.082 & 0.079 & 0.082 & 0.072 & 0.055 & 0.05 \\
\hline & Nitrate N & 100 & 449 & 485 & 390 & 490 & 550 & 540 & 570 & 510 & 610 & 490 \\
\hline & TDS & 3,000 & 3,100 & 3,380 & 2,900 & 3,800 & 4,400 & 3,700 & 4,200 & 3,600 & 4,300 & 4,200 \\
\hline \multirow[t]{5}{*}{ Aurora } & & & $\begin{array}{c}01 \text { Feb } \\
1998\end{array}$ & $\begin{array}{c}01 \text { May } \\
1998\end{array}$ & $\begin{array}{c}01 \text { May } \\
2000\end{array}$ & $\begin{array}{c}24 \text { Sep } \\
2001\end{array}$ & $\begin{array}{c}26 \mathrm{Dec} \\
2001\end{array}$ & $\begin{array}{c}22 \text { Mar } \\
2002\end{array}$ & $\begin{array}{c}26 \text { Jun } \\
2002\end{array}$ & $\begin{array}{c}02 \text { Oct } \\
2002\end{array}$ & $\begin{array}{c}11 \text { Mar } \\
2003\end{array}$ & $\begin{array}{c}23 \text { Jun } \\
2003\end{array}$ \\
\hline & Copper & 0.5 & 2.710 & 1.040 & 0.04 & 0.100 & 0.084 & 0.088 & 0.090 & 0.100 & 0.085 & 0.100 \\
\hline & Nitrate N & 100 & 108.5 & 113.2 & 190.00 & 200.000 & 190.000 & 180.0 & 180.0 & 180.0 & 180.0 & 190.0 \\
\hline & Selenium & 0.05 & 0.571 & 0.682 & 0.76 & 0.500 & 0.510 & 0.480 & 0.440 & 0.450 & 0.470 & 0.490 \\
\hline & TDS & 3,000 & $2,088.0$ & $2,068.0$ & $3,303.0$ & 3,000 & 3,200 & 2,900 & 3,000 & 3,000 & 3,300 & 3,200 \\
\hline
\end{tabular}


A comparison of the Aurora draindown chemistry with NOAELs shows that selenium is the most elevated parameter prior to, during, and following closure at this site. Selenium has an essential role in animal nutrition; however, there have been cases of selenium poisoning of livestock causing liver damage and death (USEPA, 1972). Nitrate was consistently at or above the NOAEL throughout the analysed time period while TDS and copper showed intermittent exceedances. Cadmium also occurred above its NOAEL on one occasion, but it was a minor exceedance and well below this level in all other samples. All other parameters were below their respective NOAEL.

\subsection{Risk characterisation}

The elements of concern identified during the analysis phase for each site were carried forward for risk characterisation as follows:

- Griffon - thallium, nitrate and mercury.

- Mount Hamilton - arsenic, copper, nitrate, and TDS.

- Aurora - copper, nitrate, selenium and TDS.

The parameters identified by the BLM Risk Management for Metals at BLM Mining Sites (BLM, 2004) were also selected for trend evaluation within each data set. These include arsenic, cadmium, copper, lead, mercury and zinc.

Hazard Quotients (HQ) were calculated for selected metal constituents at all three sites throughout the 10 year rehabilitation time period. An HQ of less than one indicates that adverse ecological effects are unlikely and an $\mathrm{HQ}$ of more than one suggests that further evaluation may be required to characterise potential ecological impacts on the receptors. Selections of the significant HQs for the three sites are shown in Figure 3 (Griffon), Figure 4 (Mount Hamilton) and Figure 5 (Aurora).

The HQs for the Griffon site appear to be less than one for most of the constituents, and show a general decreasing trend over time, with the exception of nitrate and thallium. HQ values for arsenic show an obvious decrease over time, changing from a quotient of 0.755 in February 1999 to 0.010 in September 2009. The highest rate of decrease in arsenic $H Q$ was seen during the end of operations and closure of the site where the HQ fell from its peak (0.830) in May 1999 to 0.270 in August 2001. From late 2001 there followed a steady decline in HQ though at a slower rate than previous. The HQs for mercury and copper also show a substantial decrease during the end of the operations of the heap leach pad. The mercury HQs indicate that the draindown solution during the end of operations period posed a high risk to wildlife (HQ 20.7); however, by November 1999, the HQ had decreased to 0.2, suggesting that ecological risks from mercury were unlikely. During the post-closure phase, the mercury HQs have remained very low $(<0.05)$. Copper values show a substantial decrease, but were below an $\mathrm{HQ}$ of one, even at the highest concentrations and therefore do not pose a risk to wildlife. Nitrate HQs show an increase from 0.44 in May 1999 to a high of 1.53 in October 2000 followed by a gradual decline after placement of the cover at closure and a sharp decline to the most recent sample In September 2009 that represents the minimum HQ of 0.4 .

The HQs for thallium show a generally increasing trend with time across the data set. This may be due to a decreasing $\mathrm{pH}$ from alkaline to neural conditions, which increases mobilisation of the metal. The HQ increased from a low of 1.136 in February 2000 to a high of 3.154 in October 2007 reflecting a moderate risk. The final data set taken in September 2009, however, shows a very low thallium HQ of 0.063, which is opposed to the general trend. It is possible that this is an anomalous result possibly due to sampling error, an extended sample holding time or laboratory detection errors. The results for other constituents from the sample compare well to other parameters and, therefore, the sample was considered to be valid. 


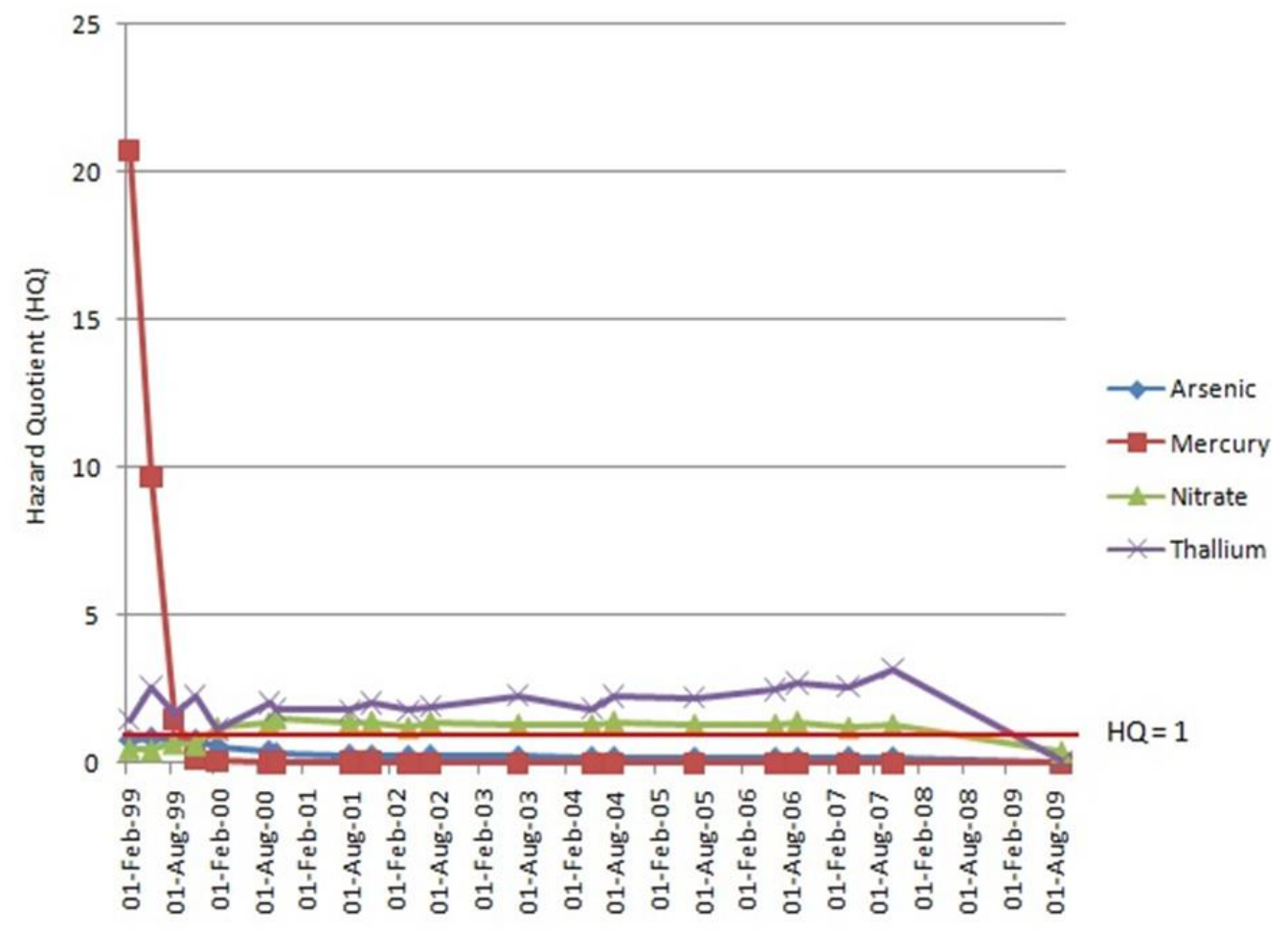

Figure 3 Changes in ecological risk (HQ) at Griffon Mine

At Mount Hamilton and Aurora, HQs were also generally low and show decreasing trends. Elevated risk values were shown for arsenic, copper, nitrate and TDS at Mount Hamilton and copper, nitrate, selenium and TDS at Aurora.

The Mount Hamilton HQs for arsenic, nitrate and TDS show an increasing trend over time and demonstrate that these parameters may currently pose a moderate level of risk to surrounding wildlife. Arsenic HQs were consistently above 1.0, ranging from a high of 15.5 in July 2005 to a low of 8.5 in September 2006, and a repeated high of 15.5 in the final sample in September 2009. The generally increasing trend in this element represents a medium to high risk to wildlife receptors and contrasts with both other sites where arsenic is below the low risk threshold and declining. Nitrate at Mount Hamilton did not follow the trend seen at the other two sites and increased throughout the rehabilitation time period, reaching its maximum $\mathrm{HQ}$ of 6.5 in the final sample of the data set (September 2009). A surge of cyanide in September 2006 may indicate that reasonable quantities of cyanide are still present in the Mount Hamilton heap, resulting in climbing nitrate concentrations as it degrades. TDS HQs are consistently elevated beyond the low risk threshold for all samples except one, and show a gradually increasing trend to a peak of 1.67 in the final sample. This represents a moderate risk but as it is close to the low risk threshold it is not of substantial concern.

Copper trends at Mount Hamilton and Aurora mirror the trend seen at Griffon, with HQs of more than one through the first few samples, after which risk drops off early in the closure period. Similar to Griffon, nitrate HQs at Aurora show an initial increase, but then show a gradual decrease for the remainder for the time period. Moderate risk levels still occur for nitrate at Aurora (maximum HQs of 2.00 in September 2001 and September 2003), but the declining trend indicates the risk will drop below the low risk threshold of one in the near future. At Aurora, $\mathrm{HQ}$ values for selenium show a generally decreasing trend within the high risk boundary for $\mathrm{HQ}$ values. The HQs decrease from a high of 15.2 in May 2000 to a low of 4.4 in September 2007, however, the last three data points in the set represent an increasing trend. Given the high HQs in this case, selenium could warrant a baseline ecological risk assessment should surface expression of draindown water become a real consideration. Although TDS HQs at Aurora were slightly beyond the low risk threshold for part of the data set (highest HQ rating of 1.1), they have remained below the threshold since 2004 suggesting that it no longer poses a risk to wildlife receptors. 
The HQs for cadmium, lead and zinc were extremely low at all three sites. The HQs show some variation over time; however, the results are based on variation in detection limits between different monitoring intervals rather than any response to closure of the heap leach pad. At Griffon, the raw data for the draindown solution clearly show that neither cadmium nor lead have ever been recorded above the limit of detection and therefore do not pose ecological threat to wildlife that may consume the water.

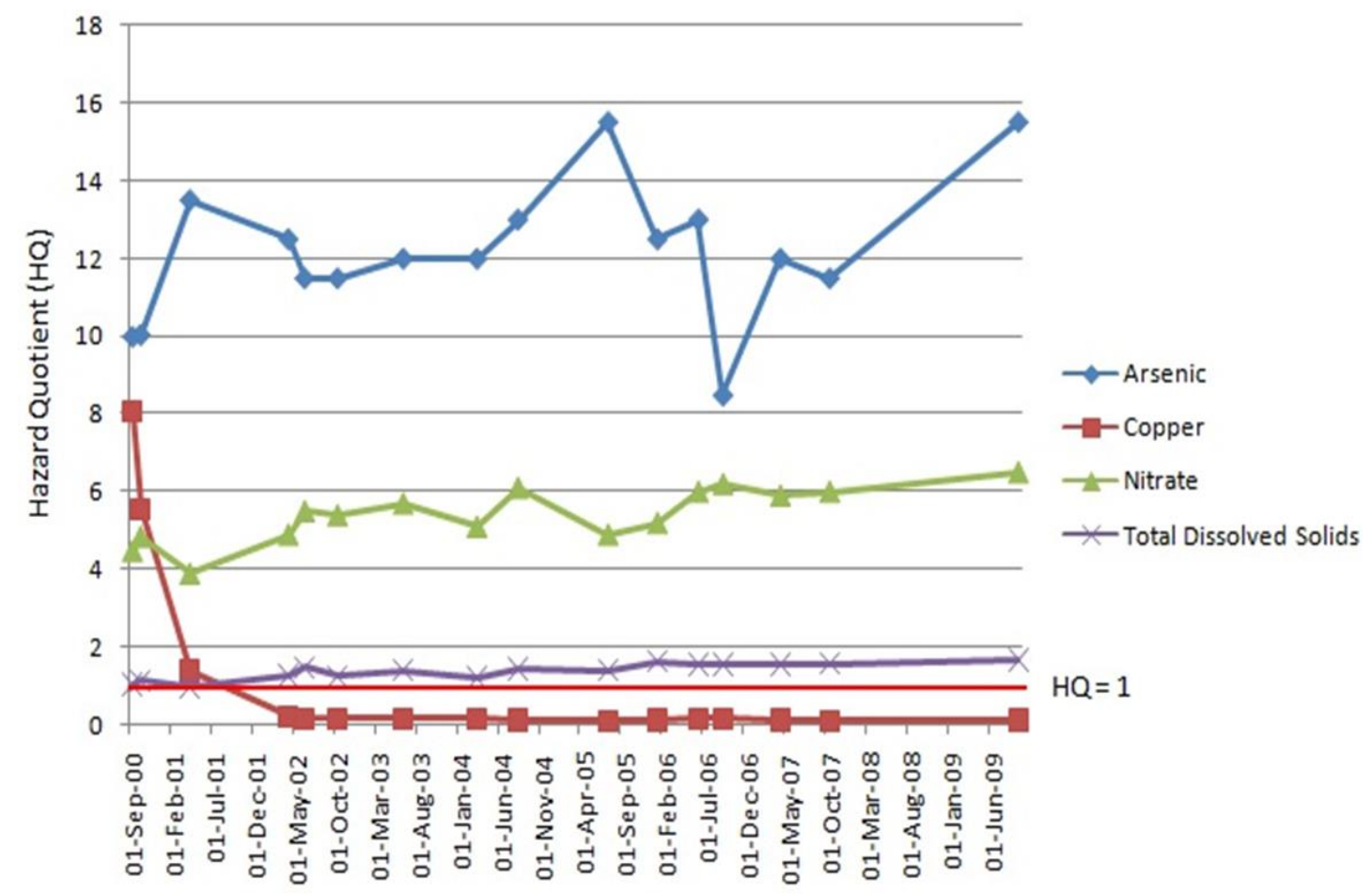

Figure 4 Change in ecological risk (HQ) at Mount Hamilton Mine

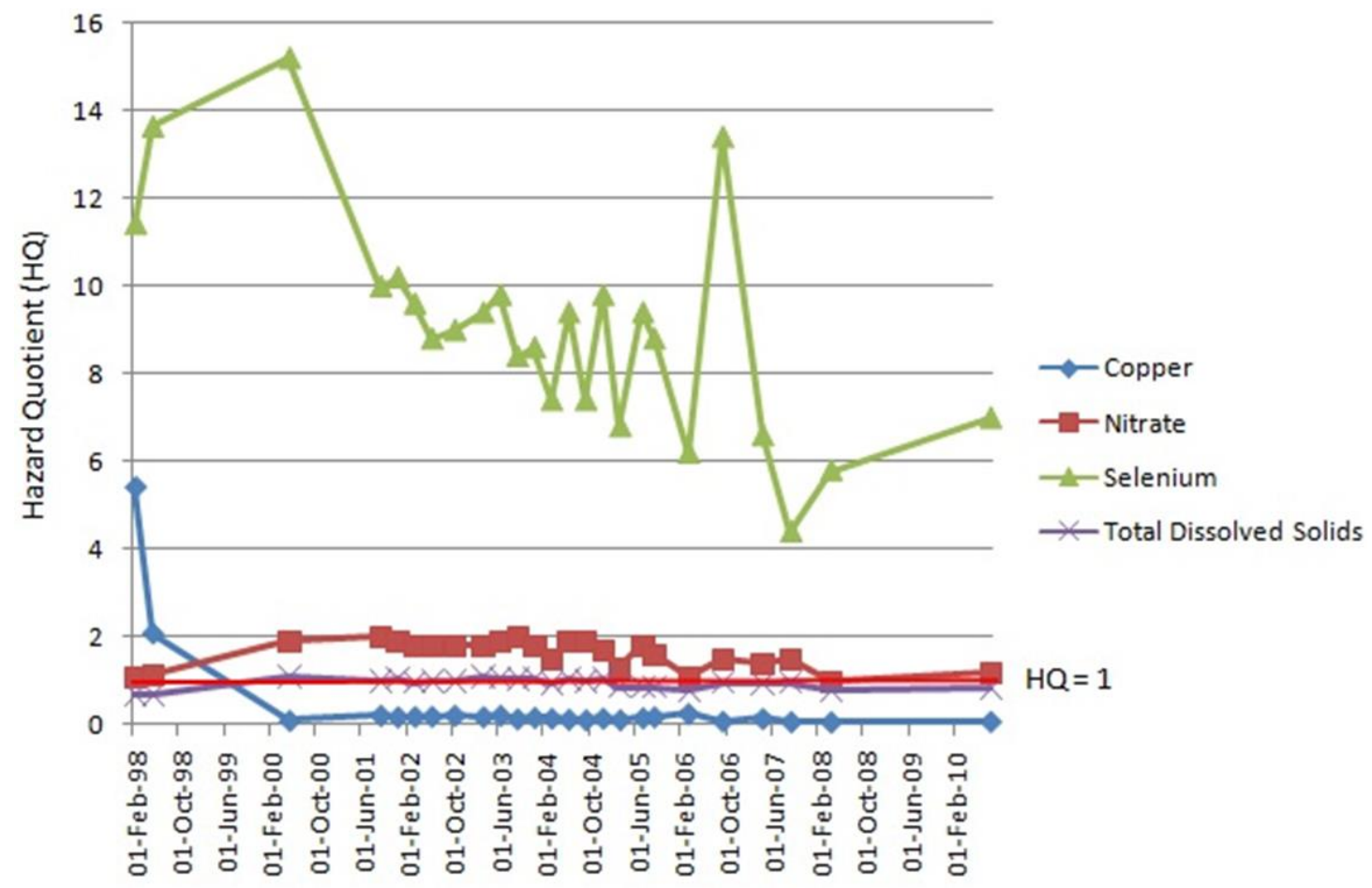

Figure 5 Changes in ecological risk (HQ) at Aurora Mine 


\section{$4 \quad$ Conclusions}

The SLERAs conducted in this study generally showed a decreasing trend of ecological risk over time, often with a sharp decrease in $\mathrm{HQ}$ immediately following the formal closure activities on the site. Removal of the leachate inventory within the heap and placement of a low-permeability cover to limit infiltration, reduce both the source of current and future metal-laden draindown, and are a likely contributor to the sharp risk reduction. In a more humid environment, revegetation may also reduce the HQ soon after closure through bioremediation, however given the slow growing desert species planted, shallow rooting systems and impermeability of the cover on which they are planted, this is an unlikely cause of the rapid decline in the study sites.

The changes in ecological risk over time, shown by this study, suggest that ecological risk is a valid rehabilitation monitoring target for the receptors included in the study in addition to the traditional growth abundance and productivity assessments used in many jurisdictions. The use of SLERAs would not require any modification to the wider monitoring programme if water quality data are already being collected, as at the case study sites evaluated here. Simple re-analysis of existing data in the context of ecological risk could provide valuable information for environmental managers on changing liabilities at the site and enable the implementation of alternative adaptive management measures in response to these changes during the rehabilitation timeframe. Surface water, although treated as a risk in this study, presents an opportunity in arid environments. If deemed suitable through the monitoring of ecological risk, the draindown water from closed heap leach pads could be put to an alternative use such as livestock watering at nearby ranches or could even enhance ecological rehabilitation itself. The presence of a perennial surface water body in a desert environment can increase the number of individuals and diversity of plant and animal species that the site can support and may also attract larger faunal groups thus improving the community structure of rehabilitated area. Further research could evaluate whether long-term trends identified in the HQs could be used to estimate the time it will take the draindown to reach target NOAELs, enabling environmental managers to plan for adaptive changes.

While adaptive management approaches have clear environmental benefits, the reality of implementation can be quite different. Once a passive disposal option has been designed at the start of the closure process, it is unlikely that a subsequent outlet for the water would be constructed without considerable pressure from neighbouring water users. The perceived risk of surface discharge may be a limiting factor for future demand for the draindown, even if the chemistry data suggest otherwise. The appetite to adaptively change the management strategy of the water numerous years into closure may therefore be low. If closure of heap leach pads could attempt to attenuate specific chemical parameters of concern at the start of closure, perhaps through improved cover design or prior to cover placement, there may be an opportunity to construct a more favourable draindown disposal option earlier in the rehabilitation process. Future study could focus on the composition and structure of this cover in the context of reducing ecological risk to achieve this objective and improve mine site ecological recovery.

\section{Acknowledgement}

Mark Willow (SRK) and Dr Peter Buckley (University of London) for their technical input to this study, and the Nevada Department of Environmental Protection for facilitating the data collection process.

\section{References}

BLM (2004) Bureau of Land Management. Risk Management Criteria for Metals at BLM Mining Sites, Technical note 390 rev. October 2004.

Geomega (2000) Closure Plan for the Mount Hamilton Heap Leach Pad, Prepared for the U.S. Forest Service, September 2000. ICMI (2011) International Cyanide Management Institute. Washington, viewed 22 July 2011,

http://www.cyanidecode.org/cyanide_chemistry.php.

MERG (2001) Mining Environment Research Group. Cyanide - The Facts. MERG Report 2001-2.

NAC (2011) Nevada Administrative Code. Chapter 445A, viewed 5 September 2011, http://www.leg.state.nv.us/nac/NAC519A.html\#NAC519A, http://www.leg.state.nv.us/nac/nac-445a.html\#NAC445A. 
Sample, B.E., Opresko, D.M. and Suter II, G.W. (1996) Toxicological Benchmarks for Wildlife: 1996 Revision, Oak Ridge National Laboratory, Oak Ridge, TN. ES/ER/TM-86/R3.

Sampson, J.R., Mellott, R.S. and Pastorok, R.A. (1996) Ecological risk assessment for a mine pit lake, Nevada USA, in Proceedings of the 20th Annual British Columbia Mine Reclamation Symposium in Kamloops, BC. The Technical and Research Committee on Reclamation, pp. 74-91.

SETAC (1997) Society of Environmental Toxicology and Chemistry. Technical issue paper: Ecological risk assessment. Pensacola, FL, USA: SETAC 4 p. Society of Environmental Toxicology and Chemistry.

Sorensen, M.T., Gala, W.R. and Margolin, J.A. (2004) Approaches to ecological risk characterization and management: Selecting the right tools for the job, Human and Ecological Risk Assessment, Vol. 10, pp. 245-269.

SRK Consulting (SRK) (2000a) Griffon Mine Heap Leach Facility Closure Plan, prepared for the U.S. Department of Agriculture Forest Service, November 2000.

SRK Consulting (SRK) (2000b) Aurora Partnership Mine Heap Leach Facility Closure Plan, prepared for the U.S. Department of Agriculture Forest Service, July 2000.

Strickland, G., Selk, G., Zhang, H. and Step, D.L. (2009) Nitrate Toxicity in Livestock, Oklahoma Cooperative Extension Service PSS2903 (http://pods.dasnr.okstate.edu/docushare/dsweb/Get/Document-1996/PSS-2903web.pdf).

Suter II, G.W. (2008) Ecological risk assessment in the United States Environmental Protection Agency: A historical overview. Integrated Environmental Assessment and Management - Volume 4, Number 3, pp. 285-289.

Suter II, G.W. (2007) Ecological Risk Assessment Second edition. CRC Press. Taylor and Francis Group. Ch 1.

United States Army Centre for Health Promotion and Preventative Medicine (USACHPPM) (2007) Wildlife Toxicity Assessment for Thallium, Prepared by Health Effects Research Program, Environmental Health Risk Assessment Program, USACHPPM Document No: 37-EJ1138-010.

USDA (2000) U.S. Department of Agriculture. Mount Hamilton Mine Heap Leach Facility Closure Project, October 20, 2000.

USDA (1997) U.S. Department of Agriculture. Final Environmental Impact Assessment, USDA Forest Service - Region 4, April 1997.

USEPA (1998) U.S. Environmental Protection Agency. Guidelines for Ecological Risk Assessment, Published on May 14, 1998, Federal Register 63(93):26846-26924 Washington DC, U.S. Environmental Protection Agency.

USEPA (1997) U.S. Environmental Protection Agency. Ecological Risk Assessment Guidance for Superfund - process for designing and conducting Ecological Risk Assessments, Ecological Response Team, U.S. Environmental Protection Agency.

USEPA (1992) U.S. Environmental Protection Agency. Framework for ecological risk assessment. Washington, DC: Risk Assessment Forum. EPA/630/R-92/001. Washington DC, U.S. Environmental Protection Agency.

USEPA (1972) U.S. Environmental Protection Agency. Water Quality Criteria, A Report of the Committee on Water Quality Criteria, United States Environmental Protection Agency, Washington D.C.

Western Regional Climate Centre (2011a) Western U.S. Climate Historical Summaries. Moorman Ranch Nevada, viewed 14 July 2011, http://www.wrcc.dri.edu/cgi-bin/cliMAIN.pl?nv5371.

Western Regional Climate Centre (2011b) Western U.S. Climate Historical Summaries, Bodie Station, California, viewed 10 July 2011, http://www.wrcc.dri.edu/cgi-bin/cliMAIN.pl?ca0943. 